\title{
In vitro anti-diabetic effect of flavonoids and pheophytins from Allophylus cominia Sw. on glucose uptake assays by HepG2, L6, 3T3-L1 and fat accumulation in 3T3-L1 adipocytes.
}

D. G. Semaan*¹, J. O. Igoli ${ }^{1,3}$, L. Young ${ }^{1}$, A. I. Gray ${ }^{1}$, E. G. Rowan ${ }^{1}$, E. Marrero²

1. Institute of Pharmacy and Biomedical Sciences, University of Strathclyde, 161 Cathedral Street, Glasgow G4 0RE.

2. National Centre for Animal and Plant Health (Centro Nacional de Sanidad Agropecuaria), San José de las Lajas, Mayabeque, Cuba.

3. Department of Chemistry, University of Agriculture, PMB 2373 Makurdi, Nigeria

*Corresponding Author: E-mail address: dima.semaan@ hotmail.com 


\begin{abstract}
Context: Based on ethno-botanical information collected from diabetic patients in Cuba and first reported as inhibiting PTP1B and DPPIV enzyme activities, Allophylus cominia (A. cominia) was identified as possible source of new drugs that could be used for the treatment of Type 2 diabetes mellitus (T2-DM).

Objective: In this study, the activity of extracts from A. cominia was tested on glucose uptake using HepG2, L6 and 3T3-L1 cells, as was as the effect of the extracts on the fat accumulation in 3T3-L1 adipocytes.
\end{abstract}

Methods: In vitro cell cultures and 2-NBDG uptake assay using HepG2, L6 and 3T3-L1 cells were carried out, followed by differentiation of 3T3-L1 adipocytes. In addition, MTT, Alamar blue, Oil Red O staining, protein assay and Western blot were conducted.

Results: On 2-NBDG uptake assay using HepG2 and L6 cells, extracts from A. cominia enhanced insulin activity by increasing glucose uptake. On HepG2 cells, insulin EC 50 of $93 \pm$ $21 \mathrm{nM}$ decreased to $13 \pm 2 \mathrm{nM}$ in the presence of the flavonoids mixture from A. cominia. In L6 cells, insulin also produced a concentration-dependent increase with an $\mathrm{EC}_{50}$ of $28.6 \pm 0.7$ $\mathrm{nM}$; $\mathrm{EC}_{50}$ decreased to $0.08 \pm 0.02 \mathrm{nM}$ and $5 \pm 0.9 \mathrm{nM}$ in the presence of $100 \mu \mathrm{g} / \mathrm{ml}$ of the flavonoid and pheophytin mixtures, respectively. In 3T3-L1 fibroblasts, insulin had an $\mathrm{EC}_{50}$ of $>1000 \mathrm{nM}$ that decreased to $38 \pm 4 \mathrm{nM}$ in the presence of the flavonoids extract. However, in adipocytes, insulin produced a significant concentration-dependent increase and an $\mathrm{EC}_{50}$ of 30 $\pm 8 \mathrm{nM}$, which was a further confirmation of the insulin responsiveness of the adipocytes. At $100 \mu \mathrm{g} / \mathrm{ml}$, both extracts decreased fat accumulation in 3T3-L1 adipocytes by two-fold in comparison to the control differentiated cells $(p<0.05)$. The crude extract of $A$. cominia did not show any enhancement of 2-NBDG uptake by 3T3-L1 adipocytes in the presence or absence of $100 \mathrm{nM}$ insulin. In addition, in adipocytes, both extracts produced a significant decrease in lipid droplets in cells and no lipid accumulation was seen after withdrawal of the extracts from the growth medium. However, neither extract had an effect on total protein concentration in cells, or on Glut-4 transporters.

Conclusion: The combined effects on glucose uptake in a concentration-dependent manner as well as the fat accumulation in adipocytes, offer further evidence of the pharmacological relevance of A. cominia extracts, flavonoids and pheophytins at molecular level, in terms of the physiopathology mechanism involved in Type 2 diabetes mellitus and obesity. 
Abbreviations: AC (A. cominia, Allophylus cominia), PTP1B (Protein Tyrosine Phosphatase 1B), DPPIV (Dipeptidyl peptidase-4), HepG2 (Hepatocellular liver carcinoma), MTT (2,3-bis(2-methoxy-4-nitro-5-sulfophenyl)-2H-tetrazolium-5-carboxanilide), Ki (inhibitory constant), TFMS ([Bis(4-trifluoromethylsulfonamidophenyl)-1,4-diisopropylbenzine), P32/98 (\{(3N[(2S, 3S)-2-amino-3-methyl-pentanoyl]-1,3-thiazolidine) hemifumarate), T2-DM (type 2 diabetes mellitus).

Keywords: Allophylus cominia; HepG2 cells; L6 cells; 3T3-L1 differentiation; Glucose uptake 


\section{Introduction}

Type 2 diabetes (T2-DM) is considered to be one of the most severe of all chronic diseases, and is one of the most widely-known metabolic illnesses (Alonso-Castro et al., 2008). It has been estimated that there are 180 million diabetic patients worldwide and this number is expected to double by 2030 (WHO, 2005). T2-DM is commonly associated with obesity (diabesity) and insulin resistance (hyper-insulinemia) is the salient feature of T2-DM and obesity. Several drugs are used for the treatment of T2-DM; however, these agents have unexpected treatment-limiting side effects. Therefore, there is a need for new anti-diabetic substances (De Souza et al., 2001; Laville and Andreelli, 2000) that have fewer side effects on patients with diabetes and do not induce obesity. Several studies carried out using plant extracts have shown significant effects on glucose uptake (Alonso-Castro et al., 2010; Alonso-Castro et al., 2008; Alonso-Castro et al., 2011; Hassanein et al., 2011; Nomura et al., 2008) and that these plant extracts have the potential to be used in the treatment of diabetes.

In this study, HepG2 cells were used as a model system for the study of the glucose uptake (Hu and Wang, 2011; Wang et al., 2011). In addition, the L6 cell line was also used as it is a common and useful model for testing glucose uptake (Wang et al., 1999; Jia et al., 2010).

Fully differentiated adipocytes are insulin-responsive and take up glucose more effectively than pre-adipocytes, with a high number of glucose transporter-4 (GLUT4) enhanced by the insulin from the intracellular compartment to the cytoplasmic membrane, resulting in an increase in the glucose uptake with lower insulin concentrations.

2-NBDG, a novel fluorescence glucose analogue probe that was initially developed to measure glucose uptake rates in cells, has also proven to be of great utility in measuring glucose uptake rates in a wide range of non-mammalian and mammalian cells in recent years. 2-NBDG has shown to be transported intracellularly by the same glucose transporters (GLUT4) as glucose. 2 deoxy-D-glucose, which is known to compete with 2-NBDG in mammalian cells, has also been used (Hassanein et al., 2011). However, 2-NBDG is known to be phosphorylated by the kinases (hexokinases) as glucose. Therefore, 2-NBDG can be trapped within the cells for an extended period of time, and can be used to monitor glucose uptake; however, phosphorylation of 2-NBDG leads to rapid degradation into non-fluorescent products. Many studies have shown that TNF- $\alpha$ inhibits adipogenesis and 3T3-L1 differentiation by down regulation of microRNAs (Cawthorn et al., 2008). TNF- $\alpha$ has also been reported in some studies to contribute to apoptosis in many cell lines (Krown et al., 1996). In type 2 diabetic patients, troglitazone acts as an insulin-sensitising agent. Troglitazone prevents the inhibitory effects of 
inflammatory cytokines such as TNF- $\alpha$ on insulin-induced adipocyte differentiation in 3T3-L1 cells (Bouaboula et al., 2005). Troglitazone has been used in studies for enhancing adipocyte differentiation in vitro (Khil et al., 1999). It has been suggested that the decrease in lipid accumulation in 3T3-L1 cells may be associated with the expression of GLUT4 transporters translocation in the cell membrane (Moon et al., 1990).

Allophylus cominia (L.) Sw (Sapindaceae), also known as Rhus cominia (L.) or Schmidelia cominia $S w$, commonly known as palo de caja, caja or caja común, is one of the best-known medicinal plants in Cuba. It was initially used as a remedy for gastrointestinal disorders, but was subsequently employed as a remedy for diabetes (Roig, 1988 and Marrero, 2007). Its use has also been reported in cases of tuberculosis and catarrhal diseases in general. In addition, medicinal properties against toothache and as a blood purifier in venereal diseases have also been attributed to this plant (Roig, 1988; Maria De Los Angeles and Gerald, 2003; García Mesa, 2014 and Marrero, 2007). Further experimental in vivo studies concluded that aqueous extracts from A. cominia leaves have antidiabetic properties and may be effective in the treatment of Type 2 diabetes (Sánchez and Marrero, 2014). Some plant uses have a common origin in the ethno-botanical practices of Caribbean people of African cultural heritage, the socalled Afro-Caribbean pharmacopoeia: examples include the use of the aerial parts of Lippia alba and Cymbopogon citratus, as well as the use of the roots and ligneous parts of Allophylus cominia, Caesalpinia bahamensis, Erythroxylum havanense, and Chiococca alba. The AfroCaribbean pharmacopoeia is that body of knowledge and practices of medicinal plants which has its origins in the cultures of African slaves brought to the Caribbean (Laguerre, 1987).

Even though the plant we studied is known to be used as an anti-diabetic in ethno-botany, pharmacological and phytochemical studies are still needed to explain the mechanism involved in the biological activity and its relevance, as well as to identify the compounds responsible for such effects regarding therapeutic targets involved in metabolic disorder diseases, Type 2 diabetes and obesity. The aim of this study was to investigate the effect of the extracts from $A$. cominia (in vitro) on glucose uptake using three different cell lines, as well as on 3T3-L1 differentiation, the formation of lipid droplets in 3T3-L1 cells and on the number of GLUT4 transporters.

\section{Materials and methods}

\subsection{Cell culture and adipocyte differentiation}


HepG2 (Hepatocellular carcinoma, human) and L6 cells (muscle cells) (donated by SIDR, University of Strathclyde) were maintained in DMEM (Dulbecco's Modified Eagle's Medium from Gibco, Invitrogen, UK), supplemented with 10\% FBS (Foetal Bovine serum), $100 \mathrm{U} / \mathrm{mL}$ of penicillin, and $100 \mu \mathrm{g} / \mathrm{mL}$ of streptomycin ( $\mathrm{Hu}$ et al., 2011) and incubated at $37^{\circ} \mathrm{C}$ in a humidified atmosphere containing $5 \% \mathrm{CO}_{2}$ in air until 70-90\% confluent. 3T3-L1 fibroblasts (ZenBio, Inc., SP-L1-F) were seeded as HepG2, reaching no more than $70 \%$ confluence; these cells were plated in DMEM 10\% NBS (newborn serum), two days post- confluence. 3T3-L1 cells were treated with a differentiation cocktail DMEM (MDI differentiation media) (Tang and Lane, 2012) supplemented with $10 \% \mathrm{FBS}, 1 \mu \mathrm{g} / \mathrm{ml}$ of insulin, $0.25 \mu \mathrm{M}$ dexamethasone and 0.5 mM IBMX (3-Isobutyl-1-methylxanthine). Two days following differentiation, the media was replaced with DMEM (10\% FBS) containing $1 \mu \mathrm{g} / \mathrm{ml}$ insulin and $1 \mu \mathrm{M}$ of troglitazone. On day 5, the media was replaced by DMEM containing $10 \%$ FBS and cells were fed with the same media until the end of the experiment.

\subsection{Extracts from A. cominia}

As explained in a previous report of the same study (Semaan et al., 2017), the phytochemical separation and identification of the compounds from the Cuban plant Allophylus cominia revealed the existence of a mixture of flavonoids (quercetrin and mearnsitrin, in addition to other minor flavonoids and fat) and a mixture of pheophytins ( $a$ and b). However, of the extracts fractionated from A.comina, all were investigated for anti-enzyme activities (DPPIV, PTP1B, $\alpha$-glucosidase and $\alpha$-amylase) (Semaan et al., 2017). The effect of fractions that showed more than $70 \%$ inhibition of PTP1B enzyme activity on glucose uptake was subsequently investigated using various cell lines. However, only the mixture of flavonoids and pheophytin A were followed for further assays.

\subsection{Cytotoxicity tests}

To evaluate cell viability of HepG2, L6, 3T3-L1 fibroblasts and adipocytes, cells were seeded at $1 \times 10^{4}$ cells $/ \mathrm{ml}$ in 96 -well culture plates and incubated for $24 \mathrm{~h}$ at $37^{\circ} \mathrm{C}$ in a humidified atmosphere containing $5 \% \mathrm{CO}_{2}$. A. cominia extracts were added at 100-1 $\mu \mathrm{g} / \mathrm{ml}$ and incubated for a further 24 h. Cell viability was tested using Alamar Blue ${ }^{\circledR}$ (Goegan et al., 1995), where $10 \%$ of the dye was added to the cells and incubated for $6 \mathrm{~h}$ at $37^{\circ} \mathrm{C}$ in $5 \% \mathrm{CO}_{2}$; the fluorescence intensity was measured using a WallacVictor ${ }^{2} 1420$ Multilabel counter at ex560-/em590nm. MTT (2,3-bis-(2-methoxy-4-nitro-5-sulfophenyl)-2H-tetrazolium-5-carboxanilide) assay was also used as cell viability test where $20 \%$ of MTT (purchased from Sigma Aldrich, UK, 
working solution of $5 \mathrm{mg} / \mathrm{ml}$ in PBS) was added to the cells and incubated for $4 \mathrm{~h}$ at $37^{\circ} \mathrm{C}$ in a humidified atmosphere containing $5 \% \mathrm{CO}_{2}$; cells were then solubilised in $100 \%$ DMSO for 5 min. The absorbance was measured using a Spectramax micro-plate reader at 570nm.

\subsection{Oil Red $O$ staining and measurement of fats}

Eight days post-differentiation, 3T3-L1 adipocytes grown in 12-well plates were washed twice with PBS (phosphatase buffer saline), fixed with $10 \%$ of formalin in PBS, and then incubated at $37^{\circ} \mathrm{C}$ in a humidified atmosphere containing $5 \% \mathrm{CO}_{2}$ for $1.5 \mathrm{~h}$. After removing the fixing solution, the cells were washed three times with distilled water. $1 \mathrm{ml}$ of oil Red-O dye was added to each well and left at room temperature for $1 \mathrm{~h}$. The dye was removed and the cells were washed three times with distilled water. To measure the fat content, $100 \%$ isopropanol was added and cells were left at room temperature for $10 \mathrm{~min}$ to allow the cells to release the dye. The optical density was measured at $540 \mathrm{~nm}$ using a Spectramax micro-plate reader.

\subsection{Glucose uptake assay}

HepG2 and L6 cells were seeded at $1 \times 10^{4}$ cells $/ \mathrm{ml}$ in a black clear bottom 96-well plate (purchased from Fisher Scientific, UK) for a direct 2-NBDG glucose uptake test. Before assaying, cells were pre-incubated at $37^{\circ} \mathrm{C}$ with extracts of $A$. cominia $(100 \mu \mathrm{g} / \mathrm{ml})$ for $24 \mathrm{~h}$; subsequently the media was replaced with Krebs-Ringer phosphate buffer (KRB) containing the plant extracts and incubated for $4 \mathrm{~h}$. Further to this, $100 \mathrm{nM}$ insulin was added in KRB buffer and cells were incubated for $45 \mathrm{~min}$, when $100 \mu \mathrm{M}$ of 2-N-7-(nitrobenz-2-oxa-1,3diazol-4-yl)amino-2-deoxy-D-glucose (2-NBDG) was added and the plate was incubated at $37^{\circ} \mathrm{C}$ for $1 \mathrm{~h}$. The reaction was terminated by washing the cells twice with ice cold PBS (Leira et al., 2002; Zou et al, 2005). The fluorescence intensity of 2-NBDG was measured on a Wallac Victor2 1420 Multi-label Counter using the excitation/emission wavelengths $485 / 535 \mathrm{~nm}$.

\subsection{Protein assay method}

Protein assay (Quick Start Bradford protein assay kit purchased from BioRad Laboratories, USA) was used for a simple and accurate procedure to determine the concentration of protein in solution. 3T3-L1 cells were pre-treated and differentiated in $25 \mathrm{~cm}^{2}$ flasks and cells were harvested in lysis buffer. BSA and Gamma-Globulin were used as standards for studying the linear range of the assay, which was $125-1000 \mu \mathrm{g} / \mathrm{ml}$ with BSA and $125-1500 \mu \mathrm{g} / \mathrm{ml}$ with 
Gamma-Globulin. Standards or unknown samples from the pre-treated 3T3-L1 cells with troglitazone, TNF- $\alpha$, flav and pheo were added to a 96 -well clear plate $(5 \mu 1 /$ well). Fibroblast cells were used as control. Blank was made using water and dye reagent. $1 \mathrm{X}$ dye reagent was then added to each well $(250 \mu \mathrm{l} /$ well $)$. The dye reagent was removed from the $4^{\circ} \mathrm{C}$ storage and warmed up at room temperature before each use. Samples and standards were incubated with the dye reagent at room temperature for $10 \mathrm{~min}$ (not more than an hour) and then the absorbance was read with a Spectramax micro-plate reader using $595 \mathrm{~nm}$.

\subsection{Western blot}

3T3-L1 cells were seeded and differentiated, in a $25 \mathrm{~cm}^{2}$ flask, addition of TNF- $\alpha(10 \mathrm{ng} / \mathrm{ml})$, flavonoids and pheophytins from A. cominia at $100 \mu \mathrm{g} / \mathrm{ml}$ was done from the beginning of the differentiation process. Three days post-differentiation, cells were washed twice with PBS. Cells were harvested and transferred into Eppendorf tubes in PBS. The PBS was removed by centrifugation at $600 \mathrm{x} g$ for 5 minutes at $4^{\circ} \mathrm{C}$ using microfuge Sigma $1-15 \mathrm{~K}$. Supernatant was discarded and cell pellet was washed twice with $1 \mathrm{ml}$ of PBS. Cell pellets were re-suspended in $1 \mathrm{ml} 1 \mathrm{X}$ lysis buffer (10X lysis buffer stock were diluted 10-fold with $9 \mathrm{ml}$ of 18 megohm water). Cells were incubated on ice for 20 minutes, and then centrifuged at $18000 \mathrm{x} \mathrm{g}$ for 15 minutes at $4^{\circ} \mathrm{C}$. The supernatants containing cell proteins were transferred into new Eppendorf tubes and analysed immediately. SDS PAGE was carried out by preparing $12 \%$ of resolving gel (RB, about $4.65 \mathrm{ml} / \mathrm{gel}$ ) and $4 \%$ of stacking gel (SB, about $1 \mathrm{ml} / \mathrm{gel}$ ), where RB was prepared by $5 \mathrm{ml}(2 \mathrm{X}) \mathrm{RB}, 4 \mathrm{ml}$ acrylamide, $1 \mathrm{ml}$ distilled water, $200 \mu \mathrm{l}$ of APS and then $8 \mu \mathrm{l}$ TEMED. SB (4\%) was prepared by $4 \mathrm{ml}(2 \mathrm{X}) \mathrm{SB}, 1.2 \mathrm{ml}$ acrylamide, $2.8 \mathrm{ml}$ distilled water, $200 \mu \mathrm{l}$ of APS, and finally the addition of $10 \mu 1$ TEMED. Then the gel was added on top of the set resolving gel, and lanes were made using a comb. The samples were then loaded at $30 \mu 1$ per lane and a marker with low molecular weight was used as a control (15 $\mu \mathrm{l})$, using a Hamilton syringe. The gel was run for half an hour at $80 \mathrm{mV}$, which was then increased to 150 $\mathrm{mV}$ for one hour. The transfer of the proteins was done by disassembling the gel plates; the gel was placed in transfer cassettes, and then the transfer was run in transfer buffer $(25 \mathrm{mM}$ Tris base, $0.2 \mathrm{M}$ glycine, $20 \%$ methanol and $\mathrm{pH} 8.9$ ) at $120 \mathrm{~mA}$ at constant AMPS and left overnight. The gel was treated with 5\% SCHIM (proteins) for an hour at room temperature prior to being incubated with Abcam antibody (1:1000, Glucose Transporter GLUT4). The cyclophilin B antibodies were purchased from Abcam PLC (Cambridge, U.K.). The polyclonal GLUT4 antibody was raised in rabbit with the immunogen located in the C-terminus of GLUT4. The polyclonal cyclophilin B antibody was raised against a C-terminal peptide of 
human cyclophilin B), and then a secondary antibody IRdye (1:12500) was added. The plate was washed three times with PBST (phosphatase buffer saline Tween $0.02 \%$ volume) for 10 minutes after the addition of the first and the second antibodies. Finally, the plate was scanned under a LI-COR Odyssey infrared scanner and the results were analysed by Licor Studio Image Lite software.

\subsection{Statistical analyses}

Data were expressed as mean \pm SEM. Graphs were generated using GraphPad Prism version 4 software. The data were analysed statistically by one way ANOVA analysis of variance and Dunnett's post-hoc test. The level of statistical significance was set at $P<0.05$.

\section{Results}

\subsection{Effect of extracts from A. cominia on cell viability}

Extracts of A. cominia $(1-100 \mu \mathrm{g} / \mathrm{ml})$ were first tested to determine their effect on cell viability; no cytotoxic effects were shown with either Alamar Blue ${ }^{\circledR}$ or MTT based cytotoxicity assays (data not shown).

\subsection{The effect of insulin and A. cominia extracts on 2-NBDG glucose uptake using HepG2 and L6 cells}

The uptake of 2-NBDG by HepG2 cells was enhanced by $100 \mu \mathrm{g} / \mathrm{ml}$ of the fraction containing flavonoids in the presence or absence of $100 \mathrm{nM}$ insulin (Fig 1.A). However, the extract containing the pheophytins had no effect on glucose uptake in this cell line. In the absence of insulin, 2-NBDG uptake by HepG2 cells was increased nine-fold. In the presence of insulin uptake, of 2-NBDG was fivefold higher than that without $100 \mathrm{nM}$ insulin. However, in the presence of both $100 \mathrm{nM}$ insulin and $100 \mu \mathrm{g} / \mathrm{ml}$ flavonoids, 2-NBDG uptake was increased by eleven-fold as shown in Fig 1.A.

2-NBDG glucose uptake was carried out in L6 cells treated for $24 \mathrm{~h}$ with $100 \mu \mathrm{g} / \mathrm{ml}$ flavonoids or pheophytins in the presence of $100 \mathrm{nM}$ of insulin (Fig 1.B). By comparison with the glucose uptake by non-treated cells (no insulin), uptake was significantly $(p<0.05)$ increased in the presence of flavonoids extracts and greatly increased in the presence of pheophytins extract. 


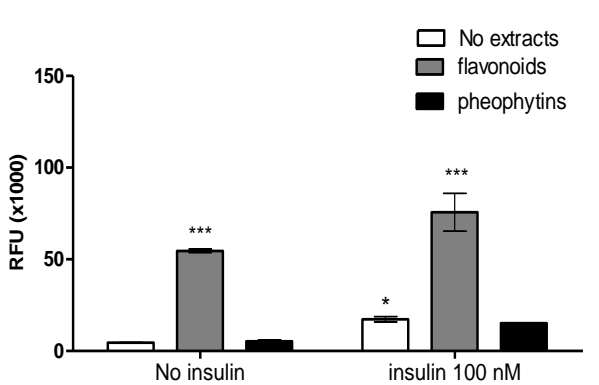

A. HepG2 cells

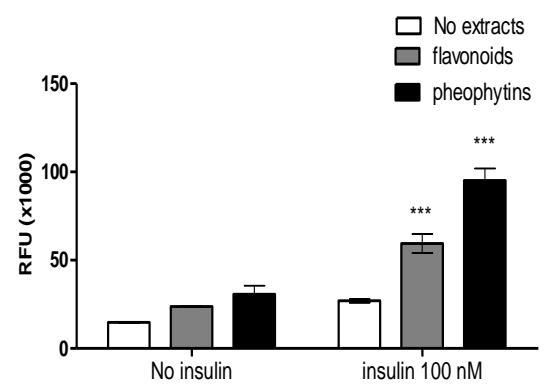

B. L6 cells

Figure 1. Flavonoids and pheophytins extracts from A. cominia increase 2-NBDG uptake by HepG2 (A) and L6 cells (B) in the presence or absence of $100 \mathrm{nM}$ insulin. Data represents the mean +/-SEM of three independent experiments. RFU is for Random Fluorescence Unit. The data were analysed by Dunnett's post-hoc test, ${ }^{*} \mathrm{P}<0.05$ versus untreated control cells.

\subsection{Effect of extracts from A. cominia on 2-NBDG glucose uptake by HepG2 and L6 cells}

As shown below in Fig 2.A, insulin produced a concentration-dependent increase in 2-NBDG glucose uptake in HepG2 cells with $\mathrm{EC}_{50} 93 \pm 21 \mathrm{nM}$. In the presence of $100 \mu \mathrm{g} / \mathrm{ml}$ of AC crude extracts, the potency of insulin in increasing 2-NBDG uptake by HepG2 cells increased, with a 6.7-fold reduction in $\mathrm{EC}_{50}$ to $13 \pm 2 \mathrm{nM}$ (Fig 2B.).

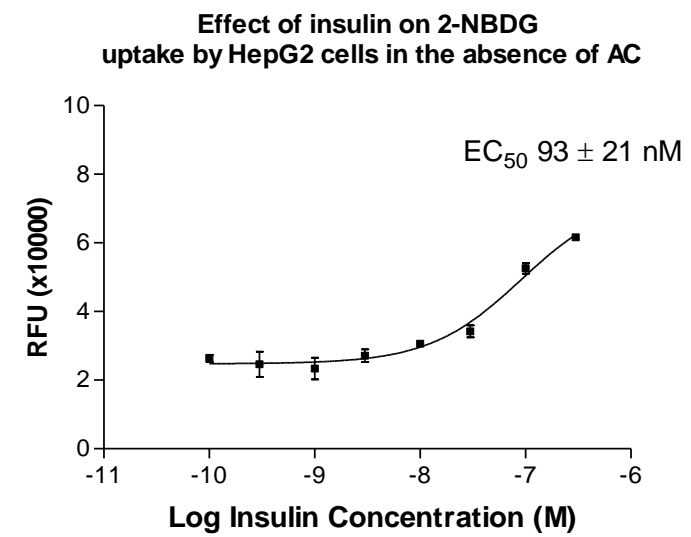

A. In the absence of $A C$

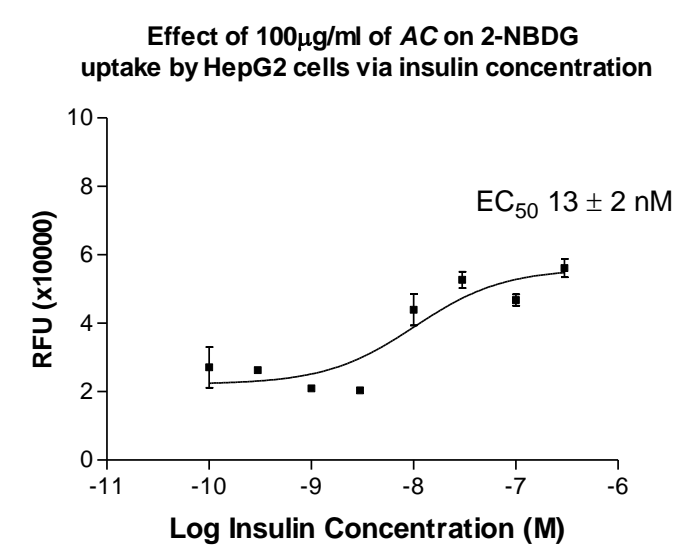

B. In the presence of $100 \mu \mathrm{g} / \mathrm{ml} \mathrm{AC}$

Figure 2. Concentration-dependent increase of 2-NBDG uptake by HepG2 produced by insulin. In the absence (A) or presence (B) of $100 \mu \mathrm{g} / \mathrm{ml}$ of the crude methanolic extract of $A$. cominia (AC). The data represent the mean of RFU +/-SEM of three independent experiments. Insulin (0.1-300 nM) in the presence or absence of $\mathrm{AC}, \mathrm{EC}_{50} 93 \pm 21 \mathrm{nM}$ and $13 \pm 2 \mathrm{nM}$ respectively. 
As shown in Fig 3.A, there was a small increase in 2-NBDG glucose uptake by L6 cells with an increasing concentrations of insulin in the absence of $\mathrm{AC}\left(\mathrm{EC}_{50} 28.6 \pm 0.7 \mathrm{nM}\right)$. L6 cells were treated for 24 hours with 10 and $100 \mu \mathrm{g} / \mathrm{ml}$ of flavonoids or pheophytin A. As shown in Figs 3.B and 3.C, insulin produced a concentration-dependent increase of the glucose uptake. In the presence of $100 \mu \mathrm{g} / \mathrm{ml}$ flavonoids and pheophytins, the uptake increased and $\mathrm{EC}_{50}$ decreased to $0.08 \pm 0.02 \mathrm{nM}$ and $5 \pm 0.9 \mathrm{nM}$, respectively.
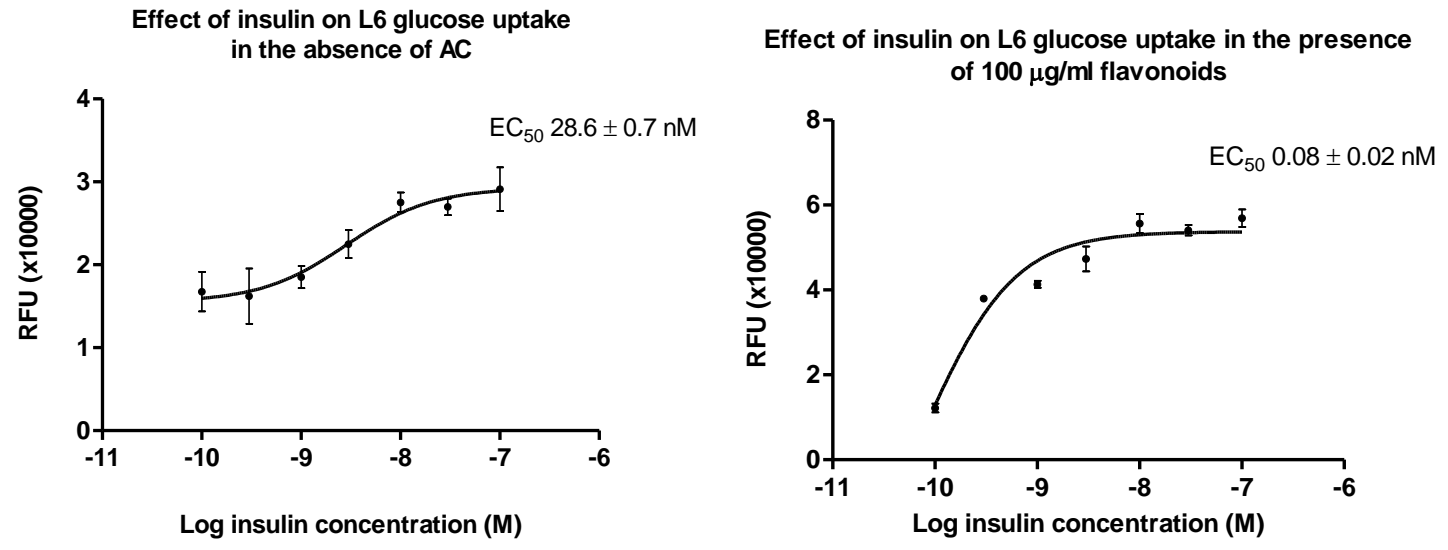

A.

B.

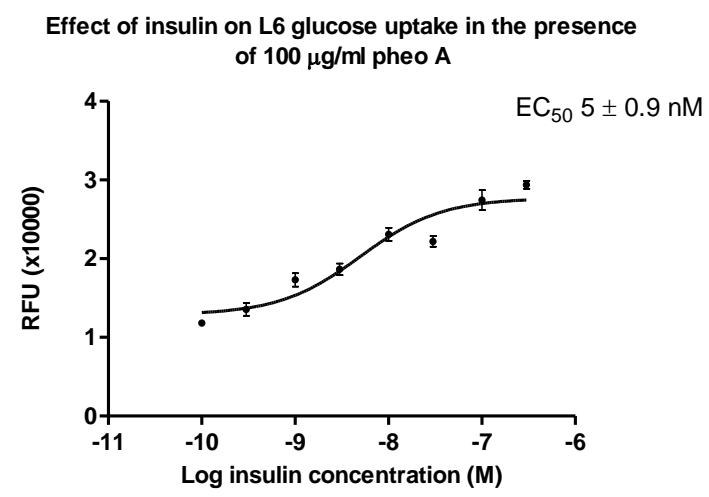

C.

Figure 3. Insulin produces an increase in 2-NBDG uptake by L6 cells (A) in the absence of $A$. cominia. (B) In the presence of $100 \mu \mathrm{g} / \mathrm{ml}$ of flavonoids from A. cominia. And (C) in the presence of $100 \mu \mathrm{g} / \mathrm{ml}$ of pheophytin A from A. cominia. Data represent the mean +/-SEM relative fluorescence unit (RFU). $n=3$.

\subsection{Effect of extracts from A. cominia on 2-NBDG glucose uptake by 3T3-L1 fibroblasts and adipocytes}

Insulin produced a concentration-dependent increase in glucose uptake in 3T3-L1 fibroblasts and fully-differentiated adipocytes. A marked enhancement of insulin-stimulated glucose uptake by 3T3-L1 fibroblasts was seen in the absence of A. cominia (Fig 4.A). A significant 
increase in 2-NBDG glucose uptake was shown in the presence of $A$. cominia methanolic crude extract by comparison with the control (in the absence of insulin) was added to the $100 \mu \mathrm{g} / \mathrm{ml}$ of $A$. cominia methanolic extract. In the presence of $100 \mu \mathrm{g} / \mathrm{ml}$ of the crude methanolic extract from $A$. cominia (AC), insulin produced a concentration-dependent increase in glucose uptake. No significant difference was shown in the presence of AC extract (Fig 4.B). However, AC extract did not enhance insulin activity in comparison to the cells untreated by AC. An increase in 2-NBDG uptake by 3T3-L1 fibroblasts was shown (Fig 4.A) in the presence and absence of the methanolic crude extract from A. cominia with increases in insulin concentrations; however, the effect of the extract was small (Fig 4.A). The $\mathrm{EC}_{50}$ of insulin without $\mathrm{AC}$ was $>1000 \mathrm{nM}$ and in the presence of the extract, the $\mathrm{EC}_{50}$ was $38 \pm 4 \mathrm{nM}$. Thus, $\mathrm{AC}$ enhances insulin activity. Insulin $(100 \mathrm{nM})$ produced an increase of glucose uptake in fully differentiated 3T3-L1 adipocytes by comparison to the basal level where no insulin was added (Fig 4.C). The crude extract of $A$. cominia did not show any enhancement of 2-NBDG uptake by 3T3-L1 adipocytes in the presence or absence of $100 \mathrm{nM}$ insulin (Fig 4.D).

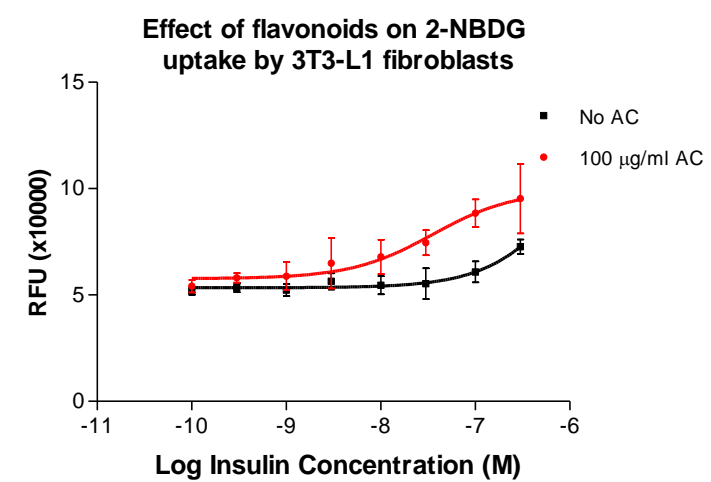

A.

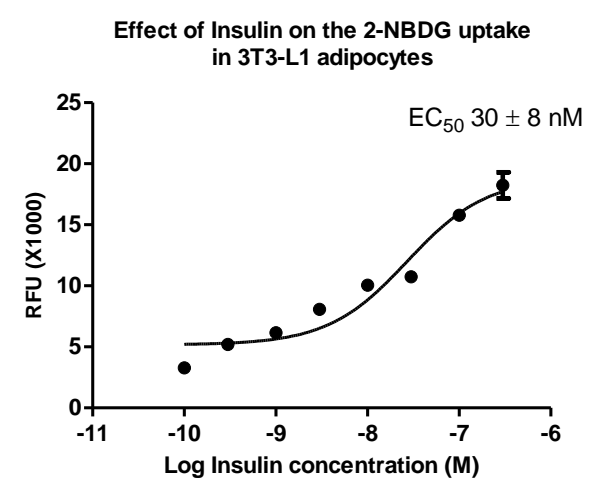

C.

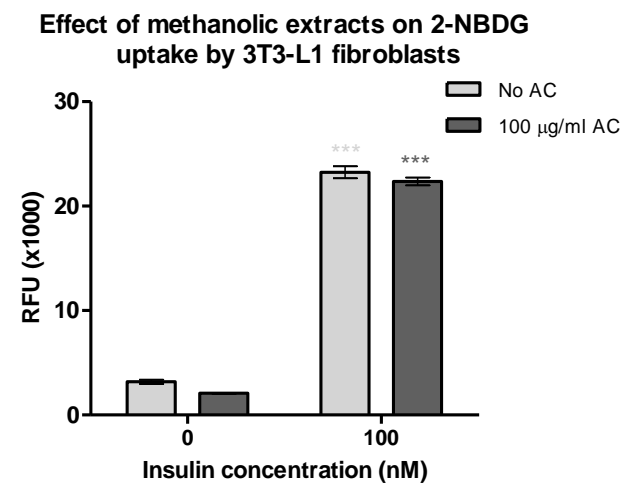

B.

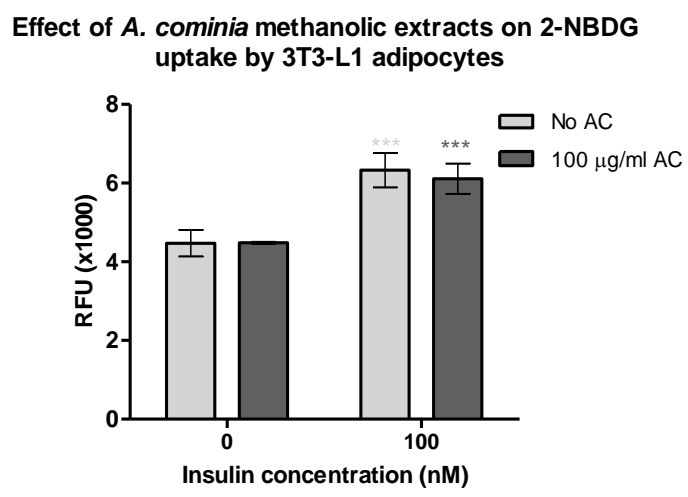

D.

Figure 4. A concentration-dependent increase of 2-NBDG uptake by 3T3-L1 produced by insulin. (A) The crude extracts from A. cominia produce a concentration-dependent uptake of 2-NBDG in non- 
differentiated fibroblasts via insulin concentration. $\mathrm{EC}_{50}$ without $\mathrm{AC}$ was $>1000 \mathrm{nM}$, and $\mathrm{EC}_{50}$ in the presence of AC was $38 \pm 4 \mathrm{nM}$. (B) Effect of A. cominia on 2-NBDG uptake by 3T3-L1 fibroblasts in the presence or absence of $100 \mathrm{nM}$ insulin. (C) Insulin concentration-dependent curve in 3T3-L1 adipocytes (0.1-300 nM) with $\mathrm{EC}_{50} 30 \pm 8 \mathrm{nM}$. (D) Effect of $A$. cominia on 2-NBDG uptake by 3T3$\mathrm{L} 1$ adipocytes in the presence or absence of $100 \mathrm{nM}$ insulin. The data represent the mean of RFU +/SEM of three independent experiments.

\subsection{Effect of A. cominia extracts on the differentiation of 3T3-L1 cells}

In comparison to control cells, there was an increase in the optical density the presence of troglitazone, and significant decrease was shown with TNF- $\alpha$. The effect of both flavonoids and pheophytins on lipid accumulation decreased by one-fold as compared to the control $(P<0.05)$ (Fig 5.A and 5.C). When the extracts were added after differentiation had been established (day 3), there was no decrease in lipid accumulation (Fig 6).

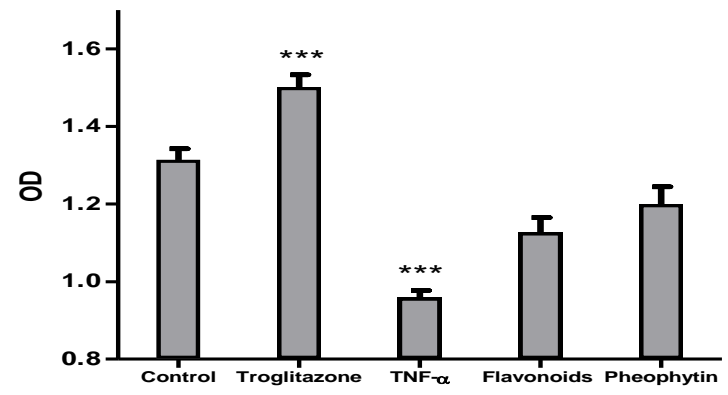

A.

\begin{tabular}{|l|l|l|l|l|l|}
\hline Day 1 & $\begin{array}{l}\text { IBMX } \\
\text { Dexamethasone } \\
\text { Insulin }\end{array}$ & $\begin{array}{l}\text { IBMX } \\
\text { Dexamethasone } \\
\text { Insulin } \\
\text { Troglitazone } 1 \mu \mathrm{M}\end{array}$ & $\begin{array}{l}\text { IBMX } \\
\text { Dexamethasone } \\
\text { Insulin } \\
\text { TNF- } \alpha 10 \mathrm{ng} / \mathrm{ml}\end{array}$ & $\begin{array}{l}\text { IBMX } \\
\text { Dexamethasone } \\
\text { Insulin } \\
\text { Flavonoids } 100 \mu \mathrm{g} / \mathrm{ml}\end{array}$ & $\begin{array}{l}\text { IBMX } \\
\text { Dexamethasone } \\
\text { Insulin } \\
\text { Pheophytin } 100 \mu \mathrm{gg} / \mathrm{ml}\end{array}$ \\
\hline Day 3 & Insulin & $\begin{array}{l}\text { Insulin } \\
\text { Troglitazone } 1 \mu \mathrm{M}\end{array}$ & $\begin{array}{l}\text { Insulin } \\
\text { TNF- } \alpha 10 \mathrm{ng} / \mathrm{ml}\end{array}$ & $\begin{array}{l}\text { Insulin } \\
\text { Flavonoids } 100 \mu \mathrm{g} / \mathrm{ml}\end{array}$ & $\begin{array}{l}\text { Insulin } \\
\text { Pheophytin } 100 \mu \mathrm{g} / \mathrm{ml}\end{array}$ \\
\hline Day 5 & DMEM 10\% FBS & DMEM 10\% FBS & DMEM 10\% FBS & DMEM 10\% FBS & DMEM $10 \%$ FBS \\
\hline
\end{tabular}

B.

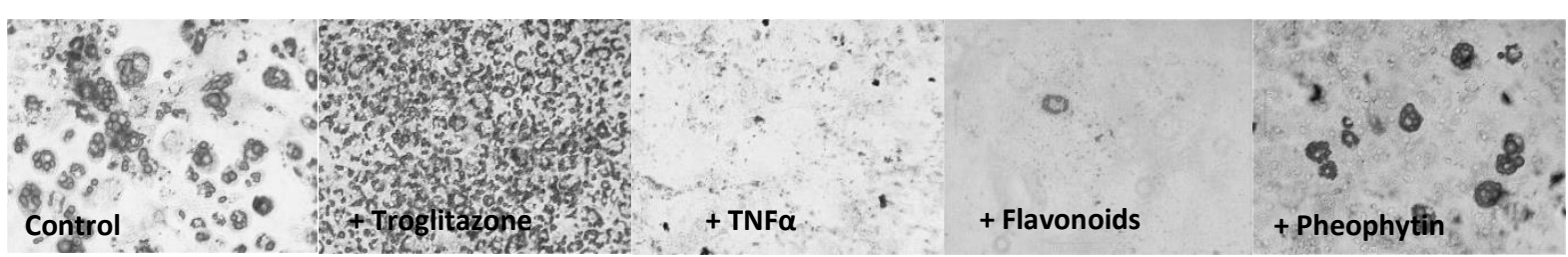

C.

Figure 5. A. Inhibitory effect of the flavonoids and pheophytins extracts from A. cominia on 3T3-L1 differentiation starting from day 1 of the differentiation. Values are presented as mean +/-SEM of three independent experiment. The data were analysed by Dunnett's post-hoc test, $\mathrm{P}<0.05$ vs control. B. Table resuming different additions over three steps of the differentiation protocol for each treatment. C. 
Morphological examination of adipocyte differentiation influenced by extracts of A. cominia and drugs treatments.

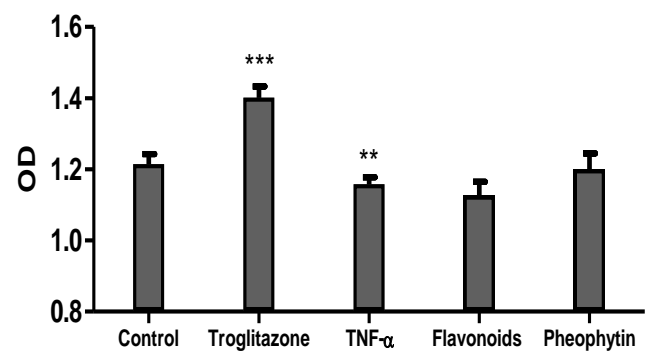

\begin{tabular}{|c|c|c|c|c|c|}
\hline Day 1 & $\begin{array}{l}\text { IBMX } \\
\text { Dexamethasone } \\
\text { Insulin }\end{array}$ & $\begin{array}{l}\text { IBMX } \\
\text { Dexamethasone } \\
\text { Insulin }\end{array}$ & $\begin{array}{l}\text { IBMX } \\
\text { Dexamethasone } \\
\text { Insulin }\end{array}$ & $\begin{array}{l}\text { IBMX } \\
\text { Dexamethasone } \\
\text { Insulin }\end{array}$ & $\begin{array}{l}\text { IBMX } \\
\text { Dexamethasone } \\
\text { Insulin }\end{array}$ \\
\hline Day 3 & Insulin & $\begin{array}{l}\text { Insulin } \\
\text { Troglitazone } 1 \mu \mathrm{M}\end{array}$ & $\begin{array}{l}\text { Insulin } \\
\text { TNF- } \alpha 10 \mathrm{ng} / \mathrm{ml}\end{array}$ & $\begin{array}{l}\text { Insulin } \\
\text { Flavonoids } 100 \mu \mathrm{g} / \mathrm{ml}\end{array}$ & $\begin{array}{l}\text { Insulin } \\
\text { Pheophytin } 100 \mu \mathrm{g} / \mathrm{ml}\end{array}$ \\
\hline Day 5 & DMEM $10 \%$ FBS & DMEM $10 \%$ FBS & DMEM $10 \%$ FBS & DMEM $10 \%$ FBS & DMEM $10 \%$ FBS \\
\hline
\end{tabular}

B.

Figure 6. A. Lack of effect of the extracts from A. cominia on 3T3-L1 differentiation starting from day 3 of the differentiation by comparison to the control when added to the cells at day 3 of the differentiation process. B. Table resuming different additions over three steps of the differentiation protocol for each treatment. OD (optical density) is presented as mean +/-SEM of three independent experiments. The data were analysed by Dunnett's post-hoc test. The table insert shows different additions over three steps of the differentiation protocol for each treatment. $* * \mathrm{P}<0.05$ and $* * * \mathrm{P}<0.01$ versus control.

\subsection{Effect of extracts of $A$. cominia on 3T3-L1 lipid accumulation}

As shown in Fig 7, the addition of flavonoids had no effect on lipid accumulation after $24 \mathrm{~h}$; therefore, a decrease in the lipid droplets was clear after $48 \mathrm{~h}$ and $72 \mathrm{~h}$. Pheophytins significantly decreased lipid droplets in 3T3-L1 adipocytes $24 \mathrm{~h}$ after addition of the extract, and this decrease was significantly greater after $48 \mathrm{~h}$ and $72 \mathrm{~h}$.

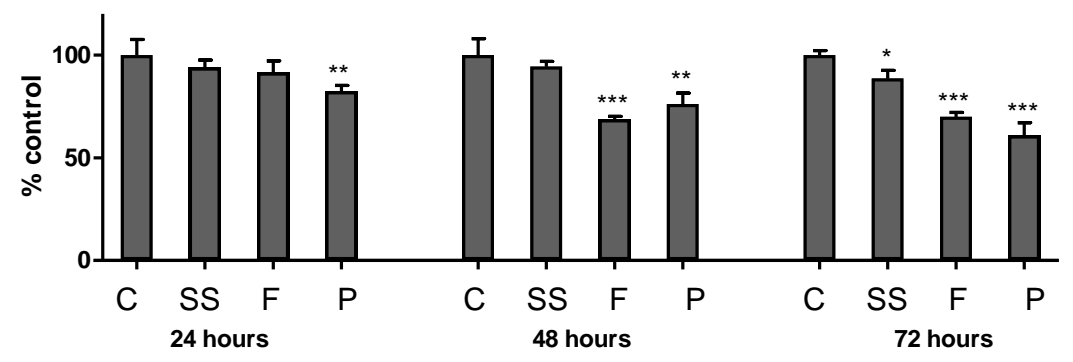

Figure 7. Flavonoids and pheophytins from A. cominia significantly reduce lipid droplets in adipocytes from $48 \mathrm{~h}$. lipid droplets were measured over three days after addition of the extracts. Values are 
presented as mean +/-SEM of three independent experiments. The data were analysed by Dunnett's post-hoc test, ${ }^{*} \mathrm{P}<0.05$ versus control. Oil Red $\mathrm{O}$ staining was done after $72 \mathrm{~h}$ of the first treatment. $\mathrm{C}$ is control, SS: serum starved cells, F: flavonoids and P: pheophytins both at $100 \mu \mathrm{g} / \mathrm{ml}$.

\subsection{Effect of withdrawal of extracts from A. cominia on the accumulation of lipid in 3T3-L1 cells}

A significant decrease of the lipid droplets inside the cells was clear, starting from $24 \mathrm{~h}$ of the addition of $100 \mu \mathrm{g} / \mathrm{ml}$ of the flavonoids and pheophytins extracts from A. cominia (Fig 8). The change of the OD decreased significantly over days, even after 5 days by comparison to the control untreated cells. After 6 days of withdrawal of the extracts, the medium was replaced with normal growth medium supplemented with $10 \%$ FBS. By comparison to the control, no fat re-accumulation was observed in the pre-treated cells with extracts of $A$. cominia. The cells pre-treated with the flavonoids containing extract showed fewer fat droplets inside the 3T3-L1 adipocytes after 5 days of the treatment (Fig 9.B) compared with the control cells (Fig 9.A).

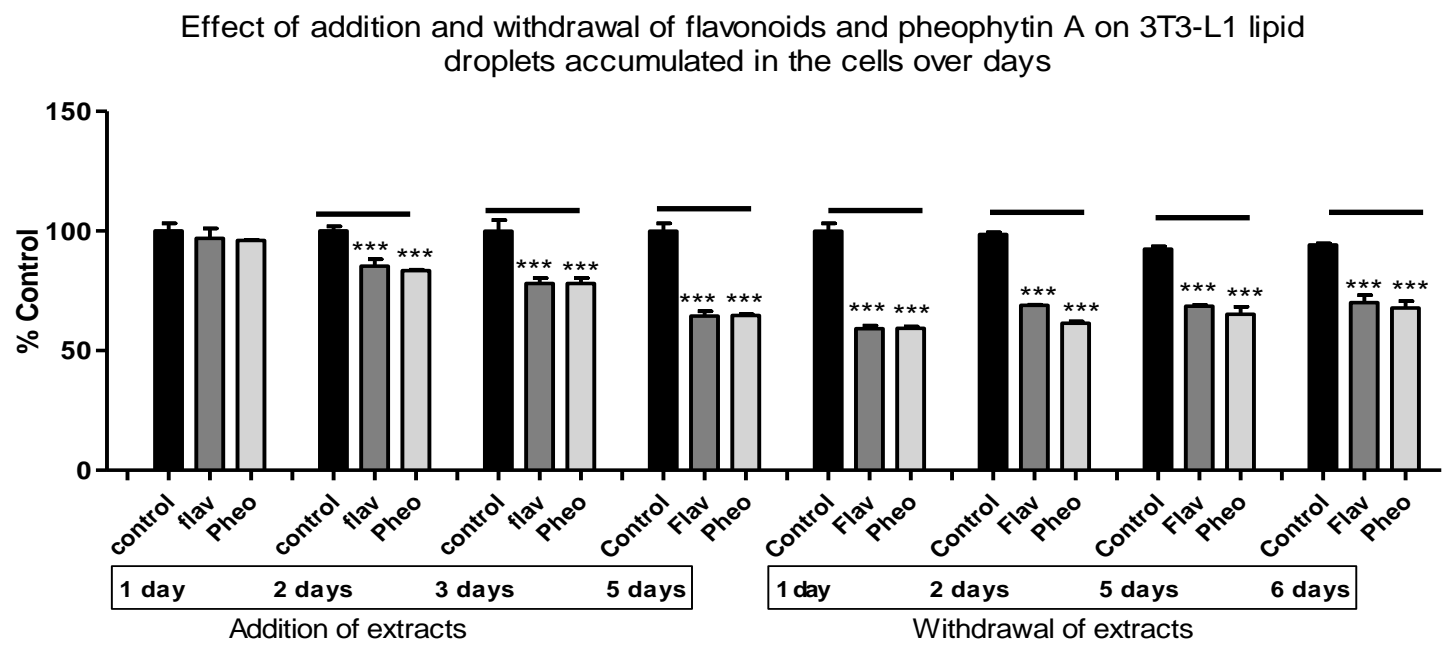

Figure 8. The inhibitory effect of $A$. cominia extracts on lipid accumulation in adipocytes over 5 days and the withdrawal effect of the extracts on the adipocytes over 6 days. Lipid droplets were quantified by Oil Red-O staining. The results represent the mean percentage control of four experimental results \pm SEM. The data were analysed by Dunnett's post-hoc test, $* * * P<0.05$ versus control at each day. 


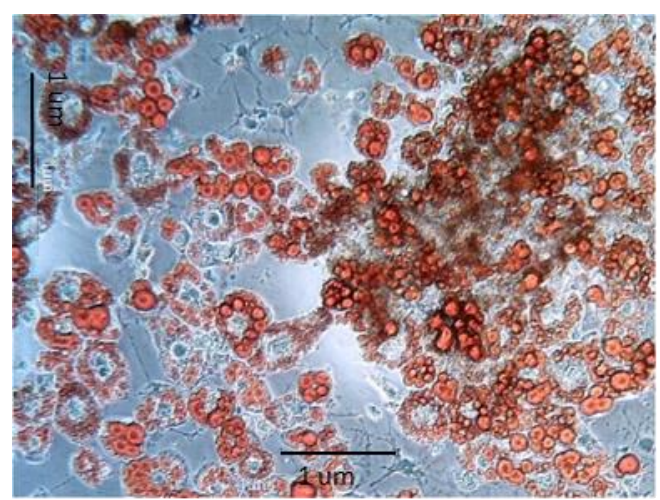

A.

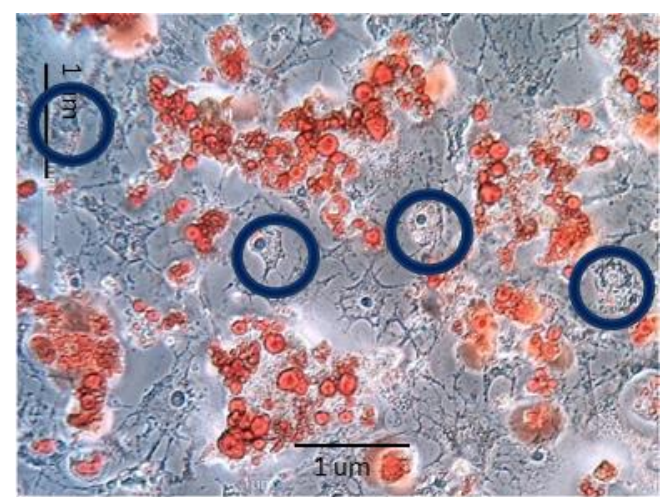

B.

Figure 9 Morphological examination of 3T3-L1 adipocytes influenced by the extracts of A. cominia. The red droplets are the fat accumulated in the cells. A. Control differentiated 3T3-L1 in the absence of extracts from A. cominia. B. Differentiated 3T3-L1 in the presence of flavonoids extact from A. cominia. The blue circles surround differentiated cells with fewer fat droplets in them.

\subsection{Effect of the extracts from A. cominia on protein concentrations in 3T3-L1 adipocytes}

As shown in Fig 10.A, BSA (standard) produced a concentration-dependent increase in the absorbance at $595 \mathrm{~nm}$. The unknown sample concentrations were calculated using the equation presented in Fig 10.A and the results are presented in Table 1. Lysis buffer was used as blank and did not show high protein concentration. No significant difference between adipocytes, fibroblasts and the pre-treated cells with TNF- $\alpha$, flavonoids and pheophytin A was shown. Furthermore, compared to the protein concentration in the fibroblasts cell lysate that was used as control, all the other metabolites from the pre-treated cells with troglitazone, TNF- $\alpha$, flavonoids and pheophytin A were similar in the total protein concentrations in these cell lysates (Fig 10.B). Protein concentration was about $1300-1600 \mu \mathrm{g} / \mathrm{ml}$ as calculated from BSA standard curve. All the results confirmed that these cell lysates contain similar protein concentrations and were able to be used for further Western blot for the identification and quantification of the GLUT4 transporters in these pre-treated 3T3-L1 cells.
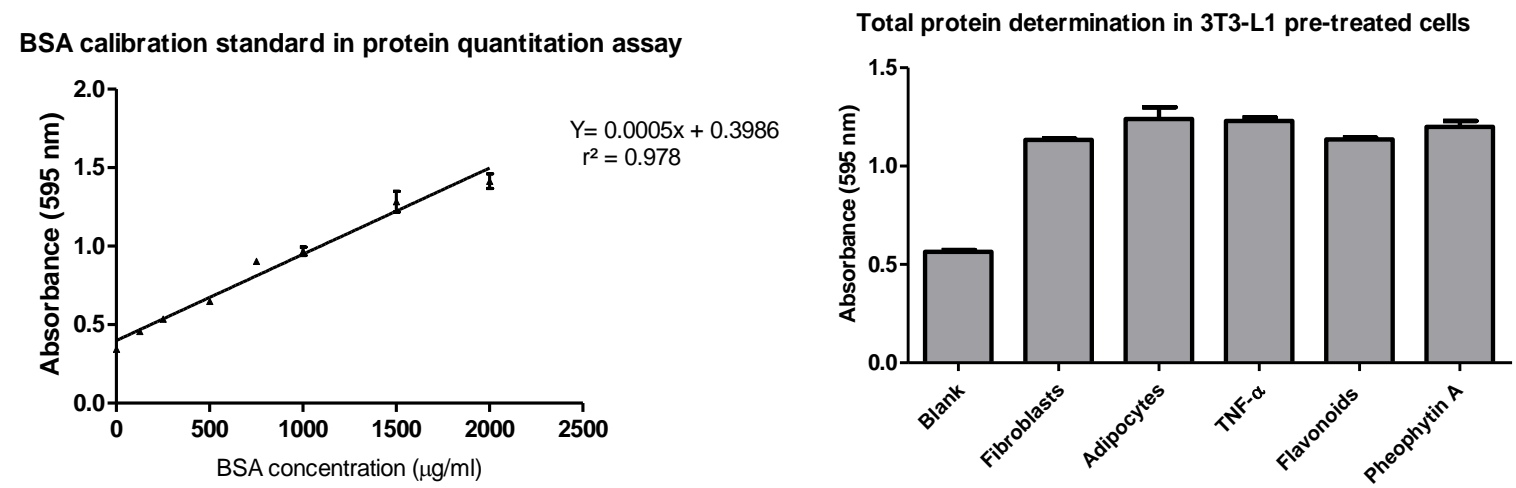
B.

Figure 10. Protein determination of the pre-treated 3T3-L1 cells with TNF- $\alpha$, flavonoids and pheophytin A. A. Standard curves of BSA standard in the protein determination assay. B. Protein determination of samples from pre-treated 3T3-L1 cells. Adipocytes and fibroblasts were used as control. Results were presented as mean absorbance +/- SEM. The data were analysed by Dunnett's post-hoc test. The absorbance was measured using micro-plate reader at $\lambda=595 \mathrm{~nm}$.

\begin{tabular}{lll}
\cline { 2 - 3 } & & Protein conc $(\boldsymbol{\mu g} / \mathbf{m l})$ \\
\cline { 2 - 3 } Adipocytes & $1.24 \pm 0.002$ & 1681 \\
Fibroblasts & $1.07 \pm 0.048$ & 1336 \\
TNF- $\alpha$ & $1.23 \pm 0.023$ & 1661 \\
Flav & $1.14 \pm 0.010$ & 1474 \\
Pheo & $1.17 \pm 0.028$ & 1534 \\
\hline
\end{tabular}

Table 1. Protein concentration in pre-treated 3T3-L1 cells. Protein concentration was calculated using BSA standard curve.

\subsection{Effect of the extracts from A. cominia on insulin-mediated GLUT4 transporters}

GLUT4 transporters from differentiated 3T3-L1 cells appeared around $46 \mathrm{kDa}$ (Fig 11.A), represented by prominent bands, whereas, cells treated with TNF- $\alpha$ showed lighter bands. The effect of TNF- $\alpha$, flav and pheo was confirmed in Fig 11.B, while a significant decrease of GLUT4 transporters only appeared in the TNF- $\alpha$ pre-treated 3T3-L1 cell line. Flavonoids and pheophytin A did not affect the GLUT4 transporters in the 3T3-L1 intracellular-membrane.

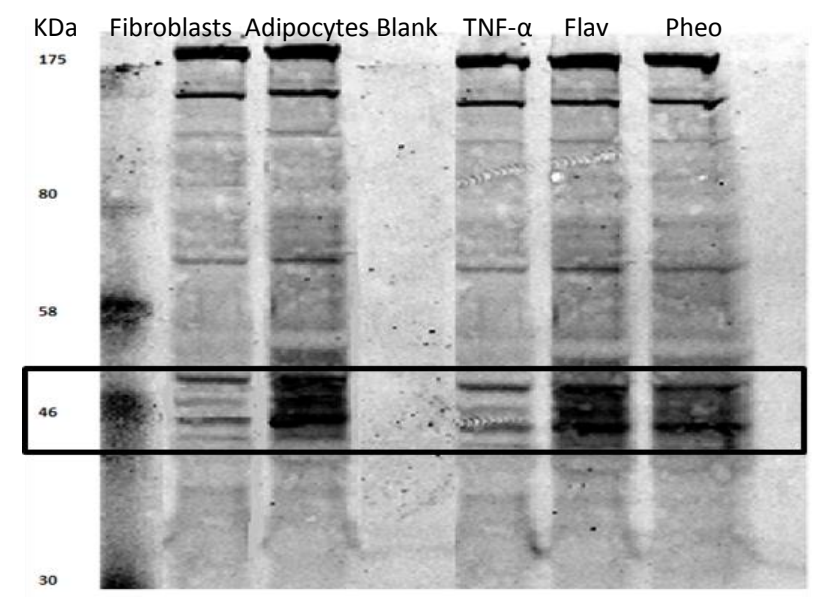

A.

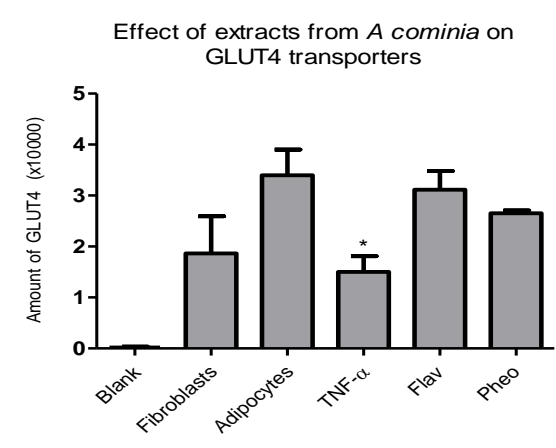

B.

Figure 11. Western blot showing the effect of TNF- $\alpha$, flav and pheo extracts of A. cominia on GLUT4 protein in plasma membranes in 3T3-L1 adipocytes. A. Representative Western blot analysis of GLUT4 
proteins in 3T3-L1 cells. B. Bar graph representative of GLUT4 transporters in fibroblasts and adipocytes and the effect of the treatments of TNF- $\alpha$, Flav and pheo. Total bands were quantitated by densitometry, and results are represented as mean amount of GLUT4 +/-SEM of three independent experiments. The data were analysed by Dunnett's post-hoc test, $* P<0.05$ versus adipocytes.

\section{Discussion and conclusion}

Both flavonoids and pheophytin A stimulate glucose uptake. However, the flavonoids and pheophytins were both in a mixture of compounds and the ratio of each compound in each sample was not identified. Therefore, further work should be carried out to confirm these ratios and to compare them with a specific biomarker as a reference. It is possible that the inhibition of PTP1B contributed to the enhancement of the glucose uptake as well as to the enhancement of insulin sensitivity in differentiated 3T3-L1, L6 and HepG2 cells. The mixture of flavonoids produced the greatest effect on glucose uptake, with 100\% inhibition of PTP1B enzyme (Semaan et al., 2017). PTP1B enzyme inhibition enhanced insulin activity of $A$. cominia by this mechanism. This was supported by reports about the effect of flavonoids on peripheral insulin sensitivity (Brahmachari, 2011; Strobel et al., 2005; Nomura et al., 2008). The hypoglycaemic activity of many plants has been linked to the presence of steroidal glycosides (McAnuff et al., 2005; Kato et al., 1995; and Dhanabal et al., 2005).

Insulin produced a concentration-dependent stimulation of 2-NBDG uptake (compared to the untreated control cells) by HepG2, 3T3-L1 fibroblasts, adipocytes and L6 cells, which confirms that these cell lines were responsive to insulin. An important functional aspect of these cells, particularly differentiated 3T3-L1 adipocytes, is insulin sensitivity. Insulin $\mathrm{EC}_{50}$ of $93 \pm 21 \mathrm{nM}$ in HepG2 cells decreased to $13 \pm 2 \mathrm{nM}$ in the presence of the methanolic crude extract of AC. In 3T3-L1 fibroblasts, insulin had an $\mathrm{EC}_{50}$ of $>1000 \mathrm{nM}$ which decreased to $38 \pm 4 \mathrm{nM}$ in the presence of AC extract. However, in adipocytes, insulin produced a significant concentrationdependent increase and an $\mathrm{EC}_{50}$ of $30 \pm 8 \mathrm{nM}$ was a further confirmation of the insulin responsiveness of the adipocytes to the insulin. The results are consistent with the general observation that newly developed adipocytes show increased insulin responsiveness and take up more glucose than fibroblasts (Xu et al., 2006). In L6 cells, insulin also produced a concentration-dependent increase with an $\mathrm{EC}_{50}$ of $28.6 \pm 0.7 \mathrm{nM}$; $\mathrm{EC}_{50}$ decreased to $0.08 \pm$ $0.02 \mathrm{nM}$ and $5 \pm 0.9 \mathrm{nM}$ in the presence of $100 \mu \mathrm{g} / \mathrm{ml}$ of flav and pheo, respectively. This serves to confirm the importance of AC extracts in lowering the insulin concentration needed in diabetic models by enhancing insulin activity. Many researchers have shown that the stimulation of glucose uptake by HepG2, L6 and 3T3-L1 fibroblasts is a well-recognised 
mechanism of action of anti-diabetic drugs and plants which have insulin-like activities (Wang et al., 2011; Wang et al., 1999; Xu et al., 2006; Alonso-Castro et al., 2008; Hu and Wang, 2011). However, the activity of $A$. cominia extracts on $2-N B D G$ glucose uptake reported in this project did not provide any information on the mechanism pathways involved in producing this activity; thus, further work is required.

Flavonoid and pheophytin extracts from A. cominia decreased lipid accumulation in 3T3-L1 once added from the first day of the initiation of the differentiation process. No effect was shown once added after three days of the differentiation initiation. This confirms that these extracts, as well as TNF- $\alpha$, are only active at the beginning of differentiation. This can be related to the expression of $\operatorname{PPAR} \gamma$, which plays an important role as an essential regulator in adipocytes differentiation (Saito et al., 2007). Extracts from A. cominia decreased lipid droplets accumulated in the cells over days. However, no lipid re-accumulation was shown after removal of the extracts over days. This can be related to the lipolytic effect of these extracts. Lipolysis in adipocytes is known to be triggered by an increase of intracellular cAMP level. cAMP activates protein kinase A and downstream lipases (Saito et al., 2007). Cells pre-treated with TNF- $\alpha$ showed a decrease in GLUT4 transporters in comparison to that of the adipocytes, as in the undifferentiated control fibroblasts, confirming that the decrease in GLUT4 transporters is due to TNF- $\alpha$ (Stephens et al., 1997). Flavonoids seemed to work differently than TNF- $\alpha$. It has been reported (Moon et al., 1990; Lee et al., 1994; Khil et al., 1999) that the hypo-glycaemic action of compounds may be due to the stimulation of glucose transport and metabolism in insulin target organs, such as 3T3-L1 adipocytes. The translocation of GLUT4 transporters is mediated by the fusion of the plasma membrane and vesicles containing GLUT4 proteins, in which the intracellular calcium causes conformational changes in the membrane compartment to facilitate the translocation process (Muller et al., 2014). The mechanism of action of flavonoids may be involved in the blockage of GLUT4 receptors rather than decreasing their translocation, thus preventing the cells from the uptake of nutrients and accumulation of fat droplets, which further implies that glucose uptake by 3T3-L1 adipocytes did not increase in the presence of flavonoids in the absence of insulin. Previous results in adipocytes showed that flavonoids inhibited the uptake of methylglucose, a substrate that enters the cells through GLUT4 transporters in 3T3-L1 adipocytes (Strobel et al., 2005). Flavonoids and their related synthetic compounds such as flavones and isoflavones, are tyrosine kinase inhibitors that cause the inhibition of glucose transport (Vera et al., 2001). As shown in the Western blot, there was an increase in GLUT4 transporters in pheophytin pre-treated cells but not as much as in the control differentiated cells, which shows that the mechanism of action of 
pheophytin in the differentiation process was different to that of the TNF- $\alpha$; that is, it blocks the GLUT4 transporters. Lysis buffer was used as blank only in the absence of any cells to ensure that the bands of GLUT4 transporters did not exist. Cells differentiated and treated with staurosporine for 24 hours did not show any GLUT4 transporters, confirming that none of the flavonoid or pheophytin extracts had apoptotic effects. Reduced glucose transporter expression is therefore likely to be a manifestation of impaired differentiation rather than a mechanism to explain reduced differentiation.

It was concluded that flavonoids and pheophytin extracts from A. cominia, with their effect on decreasing lipid droplets in the cells, could be a new candidate to prevent fat formation, thus leading to a decrease in the risk of obesity when associated with diabetes. Obesity is associated with insulin resistance, leading to an increase in the risk of diabetes. This plant was safe and non-toxic in vitro but it is suggested that its side effects be studied in vivo to evaluate it as a new drug candidate to treat diabesity and its clinical manifestations.

\section{Acknowledgments}

Many thanks to Dr Sc. Eva Marrero from CENSA, Cuba for holding and assisting with the plant material as part of the research team.

\section{Authors' contributions}

The principal author: Dr. Dima Semaan performed all research laboratory work, such as sample extraction from the plant, cell culture, bioassays, and analysis of all samples, as well as data interpretation and writing the manuscript.

The co-authors' contributions: Dr Edward Rowan and Prof Alexander Gray supervised the development of the work, helped in data interpretation and manuscript evaluation. Dr Evangelina Marrero introduced and supplied plant material, evaluated the results and helped in manuscript revision. Prof John Igoli helped in plant extraction. Mrs Louise Young helped in bioassay optimization methods.

\section{Funding}

This research did not receive any specific grant from funding agencies in the public, commercial, or not-for-profit sectors. 


\section{8. $\quad$ References}

Alonso-Castro, A. J., Miranda-Torres, A. C., González-Chávez, M. M., and Salazar-Olivo, L. A. Cecropiaobtusifolia Bertol and its active compound, chlorogenic acid, stimulate 2-NBD glucose uptake in both insulin-sensitive and insulin-resistant 3 T3 adipocytes. $J$. Ethnopharmacol. 120, 2008, 458-464.

Alonso-Castro, A.J., and Salazar-Olivo, L.A. The anti-diabetic properties of GuazumaulmifoliaLam are mediated by the stimulation of glucose uptake in normal and diabetic adipocytes without inducing adipogenesis. J. Ethnopharmacol. 118, 2008, 252-256.

Alonso-Castro, A. J., Zapata-Bustos, R., Romo-Yañez, J., Camarillo-Ledesma, P., GómezSánchez, M., and Salazar-Olivo, L. A. The antidiabetic plants Tecomastans (L.) Juss.exKunth (Bignoniaceae) and Teucriumcubense Jacq (Lamiaceae) induce the incorporation of glucose in insulin-sensitive and insulin-resistant murine and human adipocytes. J. Ethnopharmacol. 127, 2010, 1-6.

Alonso-Castro A.J., Zapata-Bustos R., Domínguez F., García-Carrancá A., and Salazar-Olivo L.A. Magnolia dealbata Zucc and its active principles honokiol and magnolol stimulate glucose uptake in murine and human adipocytes using the insulin-signaling pathway. Phytomed. 18, 2011, 926-933.

Bouaboulaa, M., Hilaireta, S., Marchanda, J., Fajas, L., Le Fura, G., and Casellasa, P. Anandamide induced PPAR $\gamma$ transcriptional activation and 3T3-L1 preadipocyte differentiation. Eur. J. Pharmacol. 517 (3), 2005, 174-181.

Brahmachari, G. Bio-flavonoids with promising anti-diabetic potentials: a critical survey. Opportunity, Challenge and Scope of Natural Products in Medicinal Chemistry 2011, 187-212.

Cawthorn, W.P., and Sethi, J.K. TNF- $\alpha$ and adipocyte biology. FEBS Letters 582 (1), 2008, 117-131.

De Souza, C.J., Eckhardt, M., Gagen, K., Dong, M., Chen, W., Laurent, D., and Burkey, B.F. Effects of pioglitazone on adipose tissue remodelling within the setting of obesity and insulin resistance. Diabetes 50, 2001, 1863-1871.

Dhanabal, S. P. Sureshkumar, M., Ramanathan, M., and Suresh, B. Hypoglycemic effect of ethanolic extract of Musa sapientum on Alloxan-induced Diabetes Mellitus in rats and its relation with antioxidant potential. J. Dietary Supp. 2 (5), 2005, 7-19.

Goegan, P., Johnson, G. and Vincent, R. Effects of serum protein and colloid on the alamar blue assay in cell cultures. Toxicol. In Vitro 9 (3), 1995, 257-266.

García Mesa, M. Antidiabetic potential of plants used in Cuba. Pharmacol. Online Arch. 1, 2014, 52-62.

Hassanein, M., Weidow, B., Koehler, E., Bakane, N., Garbett, S., Shyr, Y., and Quaranta, V. Development of high-throughput quantitative assays for glucose uptake in cancer cell lines. Molecul. Imag. Biol. 13 (5), 2011, 840-852. 
$\mathrm{Hu}$, W., and Wang, M. Diarylheotanoid from Alnushirsuta improves glucose metabolism via insulin signal transduction in human hepatocarcinoma (HepG2) cells. Biotechnol. Bioprocess Eng. 16, 2011, 120-126.

Jia, G., Mitra, A.K., Gangahar, D.M., and Agrawal, D.K. Insulin-like growth factor-1 induces phosphorylation of PI3K-Akt/PKB to potentiate proliferation of smooth muscle cells in human saphenous vein. Exp. Mol. Patho. 89 (1), 2010, 20-6.

Kato, A., Miura, T., and Fukunaga, T. Effects of steroidal glycosides on blood glucose in normal and diabetic mice. Biol. Pharm. Bull. 18 (1), 1995, 167-8.

Khil, L., Han, S., Kim, S., Chang, T., Jeon, S., So, D., and Moon, C. Effects of Brazilin on GLUT4 recruitment in isolated rat epididymal adipocytes. Biochem. Pharmacol. 58, 1999, 1705-1712

Krown, K. A., Page, M. T., Nguyen, C., Dietmar, Z., Gutierrez, V., Comstock, K. L., Glembotski, C. C., Quintana, P. J.E., and Sabbadini, R. A. Tumor Necrosis Factor alphainduced apoptosis in cardiac myocytes involvement of the sphingolipid signaling cascade in cardiac cell death. J. Clin. Invest. 98 (12), 1996, 2854-865.

Laguerre M. Afro-Caribbean Folk Medicine South Hadley, MA: Bergin and Garvey Publishers, 1987, 71-72.

Laville, M., and Andreelli, F. Mécanismes de la prise de poids en cas de normalisation glycémique. Diabetes Metab. 26, 2000, 42s-45s.

Lee, S.H., Won, H.S., Khil, L.Y., Moon, C.H., Chung, J.H. and Moon, C.K. Effects of Brazilin on glucose metabolism in epididymal adipocytes from streptozotocin induced diabetic rats. $J$. Applied Pharmacol. 2, 1994, 65-70.

Leira, F., Louzao, M.C., Vieites, J.M., Botana, L.M., and Vieytes M.R. Fluorescent microplate cell assay to measure uptake and metabolism of glucose in normal human lung fibroblasts. Toxicol. In Vitro 16 (3), 2002, 267-273.

Maria De Los Angeles L.T.-C. and, Gerald A. I. Traditional ecological knowledge and use of vegetation in south eastern Mexico: a Traditional use to treat diabetes in Cuba and Mexico case study from Solferino, Quintana Roo. Biodiversity Conserv. 12 (12), 2003, 2455-2476.

Marrero Faz E. Phytopharmaceuticals as therapeutic tools for veterinary and human therapy. Research on natural health products developed at CENSA, Havana. In: CapassoA, editor. Recent developments in medicinal plant research. Trivandrum. Research Signpost 2007, 27583.

McAnuff, M. A., Harding, W. W., Omoruyi, F. O., Jacobs, H., Morrison, E. Y., and Asemota, H. N. Hypoglycemic effects of steroidal sapogenins isolated from Jamaican bitter yam, Dioscorea polygonoides. Food Chem. Toxicol. 43 (11), 2005, 1667-72.

Moon, C.K., Lee, S.H., Chung, J.H., Won, H.S., Kim, J.Y., Khil, L.Y. and Moon, C.H. Effects of Brazilin on glucose metabolism in GLUT4 Recruitment by Brazilin 1711 isolated soleus muscles from streptozotocin induced diabetic rats. Arch. Pharm. Res. 13, 1990, 359-364. 
Muller H.K., Kragballe M., Fjorback A.W., Wiborg O. Differential regulation of the serotonin transporter by vesicle-associated membrane protein 2 in cells of neuronal versus non-neuronal origin. PLoS ONE 9 (5), 2014, e97540.

Nomura, M., Takahashi, T., Nagata, N., Tsutsumi, K., Kobayashi, S., Akiba, T., and Miyamoto, K. I. Inhibitory Mechanisms of Flavonoids on Insulin-Stimulated Glucose Uptake in MC3T3G2/PA6 Adipose Cells. Biol. Pharmacol. Bull. 31 (7), 2008, 1403-1409.

Roig, J.T. Plantas medicinales, aromáticas o venenosas de Cuba. Barnet Freixas R., editor. 1988. $2^{\text {nd }}$ edition. La Habana: Editorial Científico Técnica.

Saito, T., Abe, D., and Sekiya, K. Nobiletin enhances differentiation and lipolysis of 3T3-L1 adipocytes. Biochem. Biophys. Res. Commun. 357, 2007, 371-376.

Sánchez, Y Oliva, E Marrero. Hypoglycemic effect of Allophylus cominia (L.) Sw leaves aqueous extract in a rat model of type 2 diabetes. Bol. Latinoam. Caribe. Plant Med. Aromat. 13 (2), 2014, 198 - 204.

Semaan, D.G., Igoli, J.O., Young, L., Marrero, E., Gray, A.I., Rowan, E.G. In vitro antidiabetic activity of flavonoids and pheophytins from Allophylus cominia Sw. on PTP1B, DPPIV, alpha-glucosidase and alpha-amylase enzymes. J. Ethnopharmacol. 203, 2017, 39-46.

Stephens, J. M., Lee, J., and Pilch, P. F. Tumor Necrosis Factor - $\alpha$ - induced insulin resistance in 3T3-L1 adipocytes is accompanied by a loss of insulin receptor substrate-1 and GLUT4 expression without a loss of insulin receptor-mediated signal transduction. J. Biol. Chem. 272 (2), 1997, 971-976.

Strobel, P., Allard, C., Perez-Acle, T., Calderon, R., Aldunate, R., and Leighton, F. Myricetin, quercetin and catechin-gallate inhibit glucose uptake in isolated rat adipocytes. Biochem. J. 386, 2005, 471-478.

Vera, J. C., Reyes, A. M., Velasquez, F. V., Rivas, C. I., Zhang, R. H., Strobel, P., Slebe,J. C., Nunez-Alarcon, J. and Golde, D. W. Direct inhibition of the hexose transporter GLUT1 by tyrosine kinase inhibitors. Biochem. 40, 2001, 777-790

Wang Q., Somwar R., Bilan P. J., Liu Z., Jin J., Woodgett J. R., and Klip A. Protein kinase B/Akt participates in GLUT4 translocation by insulin in L6 myoblasts. Mol. Cell. Biol. 19, 1999, 4008-4018.

Wang, L., Xu, M. L., Rasmussen, S. K., and Wang, M. H. Vomifoliol 9-O- $\alpha$-arabinofuranosyl $(1 \rightarrow 6)-\beta$-D-glucopyranoside from the leaves of Diospyros Kaki stimulates the glucose uptake in HepG2 and 3T3-L1 cells. Carbohydr. Res. J. 4, 2011, 21.

WHO. Preventing Chronic Diseases: A Vital Investment: WHO Global Report, 2005, World Health Organization; Geneva.

Xu, M-E., Xiao, S-Z., Sun, Y-H., Ou-yang, Y., Guan, C. and Zheng, X-x. A preadipocyte differentiation assay as a method for screening potential anti-type 1 diabetes drugs from herbal extracts. Planta Medica. 72 (1), 2006, 14-19. 
Zou, C., Wang, Y., Shen, Z. 2-NBDG as a fluorescent indicator for direct glucose uptake measurement. J Biochem Biophys Methods 64, 2005, 207-215. 